
\title{
The Effect of Work Motivation, Teacher Competency And Work Environment on Education
}

\author{
Work Motivation, Teacher Competency, Work Environment, Education Quality
}

\author{
Efni Efridah \\ Postgarduate student in Universitas Negeri Medan, Sumatera Utara. \\ Email: efni101722@gmail.com
}

\begin{abstract}
This study aims to analyze the influence of head work motivation, teacher competence, and work environment on the quality of education in the Technical Vocational High School in Tebing Tinggi City. The analysis used is multiple regression analysis, which the population in this study were all teachers $(87$ individuals) in the Technical Vocational High School of Dipanegara in Tebing Tinggi City. The data collection techniques are using combine techniques, consist of: questionnaires, interviews, and documentation. The results showed that there was a significant positive influence between work motivation, teacher competence, and work environment on the quality of education simultaneously or partially. The independent variable has an influence on the quality of education by $57.30 \%$, the remaining is $42.70 \%$ is influenced by other factors outside the model. The most dominant factor affecting the quality of education is teacher competence.
\end{abstract}

Keywords- Work motivation, teacher competence, work environment, quality of education, education

\section{INTRODUCTION}

Education has an important role in a civilization for the advancement of the nation. According to [1] states that a president of the most developed countries in the world, still recognizes that investment in education is important in the progress of the nation. The Government of the Republic of Indonesia in building education in Indonesia adheres to the wrong goals of the Indonesian people stated in the opening of the fourth century of the 1945 Constitution which is to educate the lives of the nation. In line with the objectives stated in the Preamble to the 1945 Constitution, in the body of the constitution including Article 20, Article 21, Article $28 \mathrm{C}$ Paragraph (1), Article 31 and Article 32, it also mandates that the government endeavor and organize a system National Education.

The government always strives to improve the quality of education through various policies, including teacher and lecturer certification policies, school operational assistance, block grant assignments and setting national standards as outlined in Government Regulation No. 19 of 2005 concerning National Education Standards. Educational standards include content, process, labor standards, facilities and infrastructure, management, evaluation, financing and graduate competencies. then the direction of improving the quality of Indonesian education becomes clearer. If each education unit has been able to reach or exceed national education standards, the quality of the education unit can be stated high. The implementation of government policies on the standard of education in this country depends very much on the role of the education unit. With the front row is the teaching staff or teachers in each school $[1,2]$.

The teacher is the spearhead in influencing what is the output of a school unit. This is reinforced by [3,4] which reveals that the most decisive component in the education system is the teacher, so that it must receive the main attention. Provision of good services to achieve the results expected can be done if supported by human resources who have the quality and expertise in their fields. Quality and expertise refer to the competence of a teacher. Competence is defined as knowledge, skills and basic values that are reflected in the habit of thinking and acting. Another meaning of competence is the specification of the knowledge, skills, and attitudes a person has and their application in work, in accordance with the standard of performance required by the field [5]. The teacher's competence will show the true quality of the teacher. These competencies will be realized in the form of mastery of knowledge, skills and professional attitude in carrying out their duties. Therefore the Teacher Competency Standards can be interpreted as a statement about the required criteria, established and agreed upon in the form of knowledge, skills and attitudes for an education staff so that they are worthy of being called competent [1,2]. In Government Regulation No. 19 of 2005 Article 28, paragraph 3 states that teacher competency as a learning agent at the primary and secondary education levels and early childhood education includes; (1) pedagogic competence, (2) personality competence, (3) professional competence, and (4) social competence. Teacher competency standards are fully developed from the four main competencies. The fourth competency integrated in teacher performance.

To encourage teachers to improve their competence, it is also necessary to review how the teacher's work motivation. So in this study work motivation as an independent variable. Work motivation in improving teacher performance is very important to know because this involves career advancement for educators / teachers. This is reinforced by the opinion of 
[4] "... one's work performance in the organization depends on his motivation". As stated by [5] "performance is the interaction between one's abilities and their motivations". According to this opinion, performance is the sum of the abilities and work motivation that a person has. According to [6], "motivation cannot be observed directly, but can be interpreted through its behavior. This behavior can take the form of action taken in completing the task. Motivation is a driving factor that influences human behavior. Teachers who have high motivation in their work will certainly be encouraged to do the best possible work effectively and efficiently, so that the initial goals of the planned teacher can be implemented properly. Starting from this view, motivation has an important role in carrying out various tasks carried out by the teacher in order to find out achieve goals that have been set optimally.

The school work environment is defined as the quality of the physical environment which includes facilities and infrastructure as well as social quality which includes the relationship of the teacher with the principal, the relationship of the teacher to the administration, the relationship of the teacher with the teacher, the relationship of the teacher with students, and the relationship of the teacher with parents/community. While what is meant by the quality of schools in this study is the whole process of planning, structuring, and utilizing resources to realize the goals of education effectively and efficiently. The work environment is everything that is around the workers (what is meant here is students) who can influence themselves in carry out tasks that are charged, for example lighting, air temperature, space for movement, security, cleanliness, social interaction of employees and others. Vocational schools are very different from public schools. What becomes learning will be closely related to direct practice. Thus, this work environment greatly affects teaching and learning activities.

To achieve quality education, of course, good planning of educational programs is needed. In planning education to achieve quality education needs to pay attention to the conditions that influence, the right strategies, planning steps and have assessment criteria[3,4]. This study aims to see the effect of each independent variable; work motivation, teacher competence and work environment to the dependent variable is the quality of education.

\section{II.METHODOLOGY OF RESEARCH}

In this study included in the type of quantitative research because data collection using questionnaire research instrument. The research data consists of three first independent variables (X1) is work motivation, the second independent variable (X2) is the teacher's competence, the third independent variable (X3) is the environment work and the dependent variable $(\mathrm{Y})$ is the quality of education.

The main data collection method is the questionnaire, then the survey is completed with documentation and interviews. Validity test is done by correlating the variable scores, using the Pearson Product Moment formula with the help of SPSS version 22 for windows. Whereas to test reliability is done using Alpha Cronbach technique. An instrument is said to be reliable if it has a reliability or alpha coefficient of 0.6 .

The analysis technique used is multiple regression analysis. According to [7], states that multiple regression analysis is an analysis of the influence of several independent variables with one dependent variable, namely between work motivation (X1) and teacher competence (X2) and work environment (X3) on the quality of education (Y) . To test the effect of each variable $\mathrm{X}$ on the variable $\mathrm{Y}$ is partially used $\mathrm{t}$ test.

For the results of the $t$ test and $F$ test, the SPSS software program is used. As for the criteria if $\operatorname{sig} t>\alpha$, then Ho is accepted, which means there is no significant effect between variables $\mathrm{X}$ on variable $\mathrm{Y}$. If $\operatorname{sig} \mathrm{t}<\alpha$, then Ho is rejected means there is a significant influence between variables $\mathrm{X}$ on variable $\mathrm{Y}$. So also with Test $\mathrm{F}$, as for the hypothesis testing criteria using significance level $\alpha=5 \%$, is if the price of sig $\mathrm{F}$ $<\alpha$ then Ho is rejected, whereas if the price is sig F> $\alpha$ then Ho is accepted.

The population in this study were teachers of the State Technical Vocational High School in Tebing Tinggi City. With a total of 87 people taken as samples. With the sampling method, simple random sampling or simple random sampling technique.

\section{III.RESULTS AND DISCUSSIONS}

\section{A.Results}

Based on multiple linear regression analysis related to the study of dependence of a dependent variable on one or more independent variables with the aim of knowing how much influence the independent variable on the dependent variable.

TABLE 1 . The analysis regression coefficient

\begin{tabular}{|c|c|c|c|c|c|c|c|}
\hline \multirow[b]{2}{*}{ Model } & \multicolumn{2}{|c|}{$\begin{array}{l}\text { Unstandardiz } \\
\text { ed } \\
\text { Coefficients }\end{array}$} & \multicolumn{2}{|c|}{$\begin{array}{l}\text { Standardized } \\
\text { Coefficients }\end{array}$} & & \multicolumn{2}{|c|}{$\begin{array}{l}\text { Colinearity } \\
\text { Statistic }\end{array}$} \\
\hline & B & $\begin{array}{c}\text { Std. } \\
\text { Erro } \\
r \\
\end{array}$ & Beta & $\mathbf{T}$ & Sig. & $\begin{array}{l}\text { Toler } \\
\text { ance }\end{array}$ & VIF \\
\hline & & & & 8,22 & & & \\
\hline $\begin{array}{c}\text { (Constant) } \\
\text { Work }\end{array}$ & 1,91 & 232 & - & $\begin{array}{c}0 \\
2,55\end{array}$ & 000 & - & - \\
\hline motivation & 163 & 064 & 245 & $\begin{array}{c}9 \\
4,61\end{array}$ & 012 & 561 & 1,783 \\
\hline Competency & 294 & 064 & 428 & $\begin{array}{c}3 \\
2,42\end{array}$ & 000 & 598 & 1,672 \\
\hline Environment & 177 & 073 & 219 & 1 & 018 & 630 & 1,587 \\
\hline
\end{tabular}

Based on the results of the multiple regression analysis, the regression equation is obtained as follows:

$$
Y=1,910+0,163 \times 1+0,294 \times 2+0,177 \times 3
$$

From the table above shows that work motivation (X1) has a positive influence on the quality of education (Y), namely that if there is an increase in work motivation, it will improve the quality of education. The magnitude of the change in the quality of education caused by an increase in work motivation 
is 0.163 . This shows that the higher the teacher's work motivation, the better the quality of education in the State Technical Vocational High School in Tebing Tinggi and vice versa.

Based on the results of the calculation of the regression analysis above, it is also known that there is an increase in Teacher Competency (X2) also improves the Quality of Education (Y). The magnitude of the change from the Quality of Education caused by the increase in Teacher Competency is 0.294 . This shows that the higher the competency of teacher eating, the higher the quality of education.

The work environment (X3) also has a positive influence on the Quality of Education (Y), if there is an improvement in the work environment, it will also improve the quality of education in the State Technical Vocational High School in Tebing Tinggi. The magnitude of changes in the Quality of Education caused by an increase in the Work Environment is 0.177 .

To determine the effect of the factors of Work Motivation (X1), Teacher Competence (X2), and Work Environment (X3) simultaneously on the Quality of Education (Y) in the State Technical Vocational High School in Tebing Tinggi, testing was used using the $\mathrm{F}$ test. The $\mathrm{F}$ test is known to have a significant value of 0.000 which turns out to be smaller than the degree of freedom used which is equal to $0.05(0.000$ $<0.05)$. Thus it can be seen that the variables of Work Motivation (X1), Teacher Competency (X2), and Work Environment (X3) together (simultaneously) have a significant effect on the Quality of Education (Y) at the Dipanegara Technical High School in Tebing Tinggi City. It is proven by the table below:

TABLE 2. F-test (ANOVA)

\begin{tabular}{cccccc}
\hline Model & $\begin{array}{c}\text { Sum of } \\
\text { Squares }\end{array}$ & Df & $\begin{array}{c}\text { Mean } \\
\text { Square }\end{array}$ & F & Sig \\
\hline 1 & 2,122 & 3 & 707 & 37,104 & 000 \\
Regression & & & & & \\
Residual & 1,582 & 83 & 019 & & \\
\hline \multicolumn{2}{r}{ Total } & 3,704 & 86 & &
\end{tabular}

b.Predictors (Constant): Environment, Competence, Work Motivation.

To determine the influence of factors each independent variable partially on the dependent variable using t test. The results of the Regression Coefficient Analysis obtained the following results:

a. Work Motivation Variable (X1), significant value is 0.012 $<0.05$, meaning that the partial effect between the variable Work Motivation (X1) on the Quality of Education (Y) in the State Technical Vocational High School in Tebing Tinggi is significant.

b. Variable Teacher Competency (X2), significant value is $0,000<0.05$, means showing partial influence between variable Teacher Competency (X2) on Quality of Education (Y) in State Technical Vocational High School in Tebing Tinggi City is significant. c. Work Environment Variable (X3), significant value is 0.018 $<0.05$, meaning that the partial effect between the Working Environment (X3) variable on the Quality of Education (Y) in the State Technical Vocational High School in Tebing Tinggi is significant.

\section{B. Discussion}

The results of the study are in accordance with hypotheses based on existing theories. The three independent variables have a positive influence on the dependent variable in this study. From the results of data analysis, it is known for the variable work motivation (X1) obtained by the value of tcount of 2.559 with a significance level of 0.012 . Because the accompanying significance is less than $0.05(0.012>0.05)$, the research hypothesis is not rejected. In other words, the teacher's work motivation has a positive effect on the quality of education in the State Technical Vocational School in Tebing Tinggi City.

From the results of data analysis, it is known that teacher competency variables (X2) obtained tcount of 4.613 with a significance level of 0.0000 . Because the accompanying significance is smaller than $0.05(0,000>0.05)$, the research hypothesis is not rejected. It was concluded that teacher competency had a positive effect on the quality of education in the State Technical Vocational School in Tebing Tinggi City.

From the results of data analysis, it is known that for the work environment variable (X3), the value of $t$ count is 2.421 with a significance level of 0.018 . Because the accompanying significance is less than $0.05(0.018>0.05)$, the research hypothesis is not rejected. And it was concluded that the work environment had a positive effect on the quality of education in the State Technical Vocational High School in Tebing Tinggi City.

\section{CONCLUSIONS AND RECOMMENDATIONS}

Based on the results and discussion of this research it can be concluded that:

1. The work motivation of the teacher as a motivator for the teacher / educator or the teacher in carrying out teaching and learning activities as optimal as the teacher's role in transferring knowledge possessed to students of the State Technical Vocational School in Tebing Tinggi City. If an educator / teacher / teacher is eager to carry out his duties and roles, the teaching and learning process will occur maximally which will have an impact on the results of his education. That is the students of Tebing Tinggi City Technical State Vocational School as a form of education quality.

2. An educator / teacher / teacher is the spearhead in realizing the goal of realizing the quality of education to be the best. This is supported by the Republic of Indonesia Law No. 14 about Teachers and Lecturers, namely personality competencies, pedagogic competencies, professional competencies, and social competencies. 
3. Specifically for vocational high schools the learning environment of students must support the application or direct practice of what is the learning material. In other words, the working environment of the students of the State Technical Vocational High School in Tebing Tinggi has a big influence on the infrastructure and facilities as a full support for teaching and learning activities at the State Technical Vocational High School in Tebing Tinggi. Therefore a good work environment will produce the best quality education.

The suggestions that the researcher will give to the results of this study are as follows:

1. Make an increase in teacher competency through training that supports teaching and learning activities related to technical expertise.

2. The school is able to give appreciation to teachers who excel. This is expected to be able to encourage the work motivation of teachers State Technical Vocational High School in Tebing Tinggi City.
3. Adding infrastructure and facilities that support teaching and learning activities in the State Technical Vocational School in Tebing Tinggi City.

\section{REFERENCES}

[1] Ministry of Education. (2004). Primary School Teacher Competency Standards. Ministry of National Education Dirjen Dikdasmen, Jakarta.

[2] Ministry of National Education. Law No. 20 of 2003 concerning the National Education System of the Ministry of National Education, Jakarta.

[3] Government Regulation No. 19 of 2005 concerning National Education Standards. Republic of Indonesia Constitution, Jakarta.

[4] Djahiri K. (2004). Fostering and Improving Professionalism of Tasks The Role of Educators Through Increasing Teacher Competence and Schools as Learning Centers \& Agent of Changes. UPI, Bandung.

[5] Purwanto, N. 2000. Educational Psychology. Remaja Rosdakarya Publisher, Bandung.

[6] Nasution. 2004. Sociology of Education. Bumi Aksara Publisher, Bandung.

[7] Hadi, Sutrisno, 2000, Statistics. Andi Affset Publsiher, Yogyakarta. 